\title{
PENGARUH PEMBERIAN YOGHURT DAN SOYGHURT SINBIOTIK KAYU MANIS (Cinnamomum burmanii) TERHADAP KADAR TRIGLISERIDA DAN TOTAL KOLESTEROL PADA TIKUS PRA- SINDROM METABOLIK
}

\author{
Effect of Cinnamon Yoghurt and Soyghurt on Triglyceride Level and Cholesterol Total in Pra-Metabolic \\ Syndrome Rats
}
Galuh Dwi Astuti ${ }^{1}$, Deny Yudi Fitranti ${ }^{1}$, Gemala Anjani ${ }^{1}$, Diana Nur Afifah ${ }^{1}$, Ninik Rustanti ${ }^{1}$
${ }^{1}$ Program Studi Gizi, Departemen Ilmu Gizi, Fakultas Kedokteran, Universitas Diponegoro
E-mail: ninik.rustanti@gmail.com

\begin{abstract}
Dyslipidemia is one of the metabolic syndrome risk factors characterized by elevated triglyceride serum and total cholesterol. The yoghurt and soyghurt cinnamon contain lactic acid bacteria, fiber, and bioactive components which play a role to improve triglyceride serum and total cholesterol. The study aimed was to determine the effect of yoghurt and soyghurt symbiotic cinnamon on triglyceride serum and total cholesterol in pre-metabolic syndrome rats. This research was experimental with pre and post control group design. 15 male Sprague Dawley rats that were divided into 5 healthy rats as a negative control group $(\mathrm{K})$ and 10 pre metabolic syndrome rats which were induced with high fat and fructose diet for P1 (yogurt) and P2 (soygurt) which 5 rats per group. The intervention was given for 28 days with a dosage of $0,017 \mathrm{ml} / \mathrm{BW}$. P2 $(25,50 \%)$ showed reduction of triglyceride higher than P1 $(11,34 \%)$ and $\mathrm{K}(12,37 \%)$. The total cholesterol reduction in P1 $(5,65 \%)$ and P2 $(7,10 \%)$ was lower than $K(7,80 \%)$. There is no effect of yoghurt and soyghurt synbiotic cinnamon on triglyceride and total cholesterol in pre-metabolic syndrome rats. The other study which has a higher dosage and longer duration in subject with 2 criteria of pre syndrome metabolic is needed.
\end{abstract}

Keywords: yoghurt, soyghurt, cinnamon, triglyceride, total cholesterol

\section{ABSTRAK}

Dislipidemia merupakan faktor risiko sindrom metabolik ditandai kadar trigliserida dan kolesterol total diatas batas normal. Yoghurt dan soyghurt sinbiotik kayu manis mengandung bakteri asam laktat, serat, serta komponen bioaktif yang dapat memperbaiki kadar trigliserida dan kolesterol total pada pra sindrom metabolik. Penelitian ini bertujuan untuk mengetahui pengaruh pemberian yoghurt dan soyghurt sinbiotik kayu manis terhadap kadar trigliserida dan kolesterol total tikus pra sindrom metabolik. Penelitian ini merupakan true experimental dengan rancangan pre-post test control group. Subjek merupakan 15 tikus Sprague Dawley jantan yang dibagi menjadi 5 tikus normal sebagai kontrol (K) dan 10 tikus pra sindrom metabolik dengan diet tinggi lemak dan fruktosa untuk kelompok P1 (yoghurt) dan P2 (soyghurt) masingmasing 5 tikus. Intervensi yoghurt dan soyghurt diberikan sebanyak $0,017 \mathrm{ml} / \mathrm{gBB}$ selama 28 hari. Uji beda sebelum dan setelah perlakuan menggunakan Paired $t$-test atau Wilcoxon. Uji perbedaan antar kelompok menggunakan uji One-Way ANOVA atau Kruskal Wallis. Tidak terdapat penurunan kolesterol total dan trigliserida secara signifikan pada masing-masing kelompok $(p>0.05)$. Penurunan kadar trigliserida pada P2 $(25,50 \%)$ lebih tinggi daripada K (12,37\%) dan P1 (11,34\%). Penurunan kadar kolesterol total pada P1 $(5,65 \%)$ dan $\mathrm{P} 2(7,10 \%)$ lebih rendah daripada $\mathrm{K}(7,80 \%)$. Tidak terdapat pengaruh pemberian yoghurt maupun soyghurt sinbiotik kayu manis terhadap penurunan serum trigliserida dan kolesterol total. Diperlukan penelitian pada kondisi pra sindrom metabolik dengan dua kriteria yang sama, dengan dosis yang lebih tinggi atau durasi yang lebih lama.

Kata kunci: yoghurt, soyghurt, kayu manis, trigliserida, kolesterol total

Doi: $10.36457 / g i z i n d o . v 43 i 2.448$

www.persagi.org/ejournal/index.php/Gizi_Indon 


\section{PENDAHULUAN}

Sindrom metabolik merupakan sekumpulan faktor risiko yang terjadi dalam waktu bersamaan. Faktor risiko tersebut antara lain obesitas, hipertensi, resistensi insulin dan dislipidemia. Dikatakan sindrom metabolik apabila memiliki tiga atau lebih faktor risiko dari kumpulan faktor tersebut. ${ }^{1}$ Pada penelitian diketahui bahwa dari subjek sindrom metabolik 46,2 persen memiliki hipertrigliserida dan 56,0 persen memiliki HDL rendah. ${ }^{2}$ Trigliserida yang tinggi dan kadar HDL yang rendah merupakan salah satu kriteria dislipidemia. Selain itu dislipidemia juga ditandai dengan kadar kolesterol yang tinggi. ${ }^{3}$

Tingginya kadar trigliserida dan kolesterol total merupakan bagian dari faktor risiko tersebut yang jika terjadi dalam waktu lama dapat mengakibatkan penumpukan lemak dan menyebabkan terjadinya resistensi insulin sehingga berujung pada keadaan sindrom metabolik. ${ }^{4}$ Salah satu cara untuk mengatasi tingginya kadar trigliserida dan total kolesterol yaitu dengan pangan fungsional. Salah satu produk pangan fungsional yang telah lama dikenal yaitu produk susu fermentasi oleh bakteri asam laktat seperti yoghurt.

Yoghurt merupakan salah satu produk fermentasi susu dengan bantuan bakteri asam laktat (BAL) seperti Lactobacillus bulgaricus dan Streptococcus thermopillus. Bakteri asam laktat dapat menurunkan kadar kolesterol secara langsung melalui mekanisme asimilasi kolesterol dan secara tidak langsung melalui mekanisme dekonjugasi garam empedu. 5,6,7 Penelitian menunjukkan yoghurt dapat menurunkan kadar kolesterol serum pada tikus dengan hiperlipidemia dan hiperkolesterolemia. 8,9 Bakteri probiotik pada yoghurt dapat mengikat trigliserida dan kolesterol dalam darah sehingga tidak diabsorbsi oleh usus yang mengakibatkan kadar trigliserida dan kolesterol tubuh menurun. ${ }^{10}$

Inovasi yoghurt yang dapat menurunkan kadar trigliserida dan total kolesterol adalah soyghurt, yaitu yoghurt yang terbuat dari susu kedelai. Kedelai memiliki berbagai jenis fitokimia seperti isoflavon, lesitin dan vitamin $E$ yang berfungsi sebagai antioksidan dan terbukti dapat menurunkan kolesterol. ${ }^{11}$ Komponen penting dalam kedelai yang berpengaruh terhadap penurunan kadar trigliserida dan kolesterol adalah isoflavon. Isoflavon dapat menghambat absorbsi kolesterol, baik yang berasal dari diet maupun kolesterol yang diproduksi oleh hepar. ${ }^{12}$ Proses pembuatan yoghurt dari sari kacang kedelai akan menghidrolisis isoflavon menjadi senyawa isoflavon bebas yang disebut aglikon. Aglikon memiliki aktivitas lebih tinggi dalam memperbaiki trigliserida serum. ${ }^{13}$ Pemberian ekstrak kedelai $200 \mathrm{mg} / \mathrm{kg} / \mathrm{BB}$ selama 8 minggu dapat menurunkan total kolesterol $14 \%$ dan trigliserida sebesar 29 persen. ${ }^{12}$

Sekarang telah banyak dilakukan penambahan herbal pada yoghurt. Salah satu bahan herbal yang dapat digunakan yaitu kayu manis. Kayu manis merupakan salah satu herbal indonesia yang sangat mudah ditemukan dan digunakan sebagai bumbu dapur. Berdasarkan penelitian, kayu manis juga dapat menurunkan kolesterol dikarenakan adanya senyawa cynamaldehide, dan senyawa lain seperti flavonoid, tannin, dan saponin. ${ }^{14}$ Cynamaldehide merupakan turunan dari senyawa polifenol yang bersifat sebagai antioksidan. Polifenol menurunkan absorbsi kolesterol dengan cara berikatan pada cholesterol carriers saat melewati membran brush border. ${ }^{15}$ Penelitian pada kelinci yang diberikan ekstrak kasar kayu manis 500 $\mathrm{mg} / \mathrm{kelinci}$ selama 10 hari, dapat menurunkan kadar trigliserida kelinci 81 persen dan total kolesterol 68 persen. ${ }^{15}$

Karagenan adalah hasil ekstraksi dari rumput laut merah (Rhodophyceae) yang merupakan serat alami. Karagenan bersifat hipokolesterolemik dan kandungan serat pangan pada karagenan sebesar 68,55 persen. ${ }^{16}$ Penambahan gula stevia dilakukan untuk memberikan rasa manis. Stevia memiliki tingkat kemanisan 200-250 kali dari pada gula bisa, tidak memiliki kalori, aman serta memiliki efek antihiperlipidemik. ${ }^{17}$

Berdasarkan manfaat dan beberapa pangan tersebut, maka penelitian ini bertujuan untuk menguji pengaruh pemberian yoghurt dan soyghurt sinbiotik kayu manis terhadap kadar trigliserida dan kolesterol total pada tikus Sprague dawley pra-sindrom metabolik.

\section{METODE PENELITIAN}

Penelitian ini merupakan penelitian eksperimental dengan rancangan pre post test 
only randomized control group design. Penelitian ini dilakukan di Laboratorium Hewan Coba Fakultas Kedokteran UNDIP. Subjek pada penelitian ini adalah tikus jantan galur Sprague dawley berumur 8-12 minggu. Berat badan tikus yang digunakan sekitar 100-210 gram. Kriteria eksklusi yang termasuk dalam penelitian ini yaitu tikus tidak bergerak secara aktif, tikus mati, bobot tikus menurun mencapai <100 gram dan tikus mengalami perubahan perilaku (tidak mau makan, minum dan lemas). Besar subjek minimal untuk setiap kelompok ditentukan dengan menggunakan rumus WHO dimana hasilnya yaitu 5 ekor tikus dalam setiap kelompok. Total tikus yang digunakan berjumlah 15 ekor dengan rincian 5 tikus sehat yang menjadi kelompok kontrol (K) dan 10 tikus dengan pemberian diet tinggi lemak dan fruktosa yang nantinya akan menjadi presindrom metabolik yang akan diintervensi dengan menggunakan yoghurt (P1) dan soyghurt (P2) masing-masing 5 tikus per kelompok. Pada penelitian ini terdapat 3 kelompok perlakuan, terdiri dari: 1) kelompok kontrol (K), tikus normal tanpa perlakuan; 2) kelompok perlakuan $1(\mathrm{P} 1)$, tikus pra sindrom metabolik yang diberi intervensi pemberian yoghurt sebanyak $0,017 \mathrm{ml} / \mathrm{gBB} / \mathrm{hari} ; 3)$ kelompok perlakuan 2 (P2), tikus pra sindrom metabolik yang diberi intervensi pemberian soyghurt sebanyak $0,017 \mathrm{ml} / \mathrm{gBB} / \mathrm{hari}$.

Penelitian pendahuluan dilakukan pada penelitian ini, yaitu pembuatan yoghurt dan soyghurt sinbiotik kayu manis. Penelitian pendahuluan dimulai dari pembuatan ekstrak kayu manis dengan menggunakan metode infundasi yaitu dengan perebusan pada suhu $90^{\circ} \mathrm{C}$ selama 15 menit menggunakan pelarut air. Setelah mendapatkan filtrat cair, maka filtrat dimasukkan ke dalam evaporator untuk mendapatkan ekstrak kental. Selanjutnya, pembuatan yoghurt dan soyghurt dibuat dengan susu yang ditambah dengan inulin 2persen, stevia 2 persen serta gula pasir 5 persen yang dihomogenisasi. Campuran dipasteurisasi dengan suhu $70^{\circ} \mathrm{C}$ selama 30 detik, saat suhu turun mencapai $45^{\circ} \mathrm{C}$ dilakukan penambahan starter sebanyak 10persen dan kayu manis 4persen. Kemudian campuran tersebut diinkubasi selama 18-20 jam. Penambahan karagenan dilakukan setelah inkubasi sebanyak 2persen. Pada pembuatan susu kedelai digunakan metode illinois, yaitu $125 \mathrm{~g}$ kedelai yang sudah dibersihkan direndam dalam air 240 $\mathrm{ml}$ yang sudah ditambahkan larutan sodium bikarbonat $\left(\mathrm{NaHCO}_{3}\right)$ 0,5persen selama 8-12 jam. Kedelai ditiriskan kemudian dihaluskan menggunakan grinder dengan perbandingan kedelai : air $80-90^{\circ} \mathrm{C}$ yaitu 1:8 serta diambil sarinya. Sari kedelai kemudian dipasteurisasi menjadi susu dengan langkah yang sama dengan pembuatan yoghurt.Pada percobaan pendahuluan, diperoleh kadar antioksidan yoghurt yaitu sebesar 11 persen dan soyghurt sebesar 6persen berdasarkan uji DPPH. Berdasarkan metode TPC, BAL yang ada pada yoghurt sebanyak $5,4 \times 10^{8} \mathrm{CFU} / \mathrm{ml}$ dan soyghurt sebanyak $3,8 \times 10^{7} \mathrm{CFU} / \mathrm{ml}$.

Pada penelitian hewan coba, seluruh tikus diaklimatisasi selama 7 hari dalam kandang individu dengan siklus pencahayaan 12 jam, mendapat makan standar AD II confeed dan minum ad libithum. Tikus dikandangkan secara individu dengan suhu kandang $28-32^{\circ} \mathrm{C}$. Kandang dibersihkan setiap hari dan dilakukan penimbangan berat badan tikus setiap tiga kali sehari. Setelah masa aklimatisasi, 5 tikus $\mathrm{K}$ hanya diberikan pakan standar dan 10 tikus yang terdiri dari kelompok P1 dan P2 diberikan pakan tinggi lemak dan fruktosa yaitu berupa minyak babi $2 \mathrm{ml} / 200 \mathrm{gBB} /$ hari, kuning telur puyuh $1 \mathrm{ml} / 200 \mathrm{gBB} /$ hari dan fruktosa murni sebanyak $1 \mathrm{ml} / 200 \mathrm{gBB} / \mathrm{hari}$ yang kemudian dihomogenisasi dan diberikan melalui sonde selama 4 minggu. Pemberian pakan tinggi lemak dan fruktosa dilakukan untuk mendapatkan kondisi hiperglikemia (>110 $\mathrm{mg} / \mathrm{dl}$ ), hipertrigliserida (>114 mg/dl) dan HDL rendah ( $<35 \mathrm{mg} / \mathrm{dll}$ ) pada tikus. Selanjutnya tikus dipuasakan 8-10 jam dan dilakukan pengambilan darah tikus sebanyak $2 \mathrm{ml}$ melalui plexus retroorbitalis untuk memastikan kondisi pre sindrom metabolik sekaligus pemeriksaan darah sebelum diberikan intervensi. Kadar glukosa darah diukur menggunakan metode GOD-PAP, kadar trigliserida menggunakan metode glycerol phospahate oxidase-phenol amino phenazone (GPOP-PAP), kolesterol HDL dan kolesterol total menggunakan metode cholesterol oxidase - phenol aminophenazone (CHOD-PAP).

Pada masa intervensi, tikus $\mathrm{P} 1$ diberikan yoghurt kayu manis dan P2 diberikan soyghurt kayu manis, sedangkan kelompok kontrol hanya diberikan pakan standar dan tidak diberikan intervensi. Dosis pemberian yoghurt dan 
soyghurt didasarkan pada dosis penelitian sebelumnya, yaitu dosis efektif yoghurt sinbiotik dalam penurunan total kolesterol, kolesterol LDL dan trigliserida, serta peningkatan kolesterol HDL adalah $125 \mathrm{ml} /$ hari selama 4 minggu..$^{18}$ Perhitungan dosis menggunakan perbandingan allometric scalling dengan membandingkan dosis pada manusia dan tikus, sehingga didapatkan dosis pemberian 0,017 g/BB tikus/ hari selama 28 hari. Setelah intervensi selanjutnya tikus dipuasakan 8-10 jam dan diambil darahnya sebanyak $2 \mathrm{ml}$ melalui plexus retroorbitalis untuk pemeriksaan darah sesudah perlakuan di Laboratorium IDEAL. Kadar glukosa darah diukur menggunakan metode GOD-PAP, kadar trigliserida menggunakan metode glycerol phospahate oxidase-phenol amino phenazone (GPOP-PAP), total kolesterol menggunakan metode cholesterol oxidase - phenol aminophenazone (CHOD-PAP).

Pengolahan data dilakukan dengan program komputer. Normalitas data diuji menggunakan uji saphiro-Wilk $\leq 30$. Kadar kolesterol total dan trigliserida pre post test diuji dengan uji statistik paired t-test serta uji One Way ANOVA. Data asupan pakan dan berat badan juga diuji menggunakan uji paired t-test dan One Way ANOVA. Seluruh pelaksanaan penelitian ini telah memperoleh persetujuan dari
Komite Etik Penelitian Kesehatan (KEPK) Fakultas Kedokteran Universitas Diponegoro/Rumah Sakit Umum Pusat dr. Kariadi No. 87/EC/H/FK-RSDK/XII/2017.

\section{HASIL}

\section{Kondisi Subjek Pra-Sindrom Metabolik setelah Pemberian Pakan Tinggi Lemak dan Tinggi Fruktosa}

Berdasarkan pengkondisian pra sindrom metabolik didapatkan hasil bahwa dari tiga indikator yang digunakan dua diantaranya memenuhi kriteria sindrom metabolik. Berdasarkan Tabel 1, kelompok $\mathrm{K}$ memiliki ratarata trigliserida, glukosa darah puasa (GDP) dan kolesterol HDL pada rentang normal. Pada kelompok P1 dan P2 telah memenuhi kondisi hiperglikemia dan hipertrigliserida.

\section{Berat Badan Rerata Tikus}

Berdasarkan Tabel 2, terdapat peningkatan berat badan pada fase aklimatisasi, pengkondisian pra sindrom dan intervensi, kecuali kelompok perlakuan $1 \quad(p>0,05)$ pada fase intervensi. Berdasarkan uji one way ANOVA, tidak terdapat perbedaan signifikan antar kelompok pada semua fase baik aklimatisasi, pengkondisian pra sindrom metabolik dan intervensi.

Tabel 1

Pengkondisian Tikus Pra-Sindrom Metabolik

\begin{tabular}{llll}
\hline Kelompok & $\begin{array}{l}\text { Kadar Gula Darah Puasa } \\
\text { Rerata } \pm \text { SD }\end{array}$ & $\begin{array}{l}\text { Kadar Trigliserida } \\
\text { Rerata } \pm \text { SD }\end{array}$ & $\begin{array}{l}\text { Kadar kolesterol HDL } \\
\text { Rerata } \pm \text { SD }\end{array}$ \\
\hline Kontrol & $83,34 \pm 16,86^{\mathrm{b}}$ & $78,00 \pm 18,53$ & $44,00 \pm 6,25$ \\
Perlakuan yoghurt (P1) & $131,96 \pm 32,32^{a^{*}}$ & $115,20 \pm 49,44^{*}$ & $38,80 \pm 10,94$ \\
Perlakuan soyghurt (P2) & $143,88 \pm 38,13^{a^{*}}$ & $115,06 \pm 25,49^{*}$ & $36,80 \pm 9,26$ \\
p value & $0,024^{2}$ & $0,182^{2}$ & $0,452^{2}$ \\
\hline
\end{tabular}

${ }^{*}$ Memenuhi kriteria pra sindrom metabolik (hiperglikemia, hipertrigliserida), ${ }^{1}$ Uji Kruskal Wallis, ${ }^{2}$ Uji One way Anova, a,b) Notasi yang berbeda menunjukkan perbedaan yang bermakna pada uji lanjut Mann Whitney, ${ }^{\text {** }}$ signifikan $(p<0,05)$

Tabel 2

Rerata Berat Badan Tikus

\begin{tabular}{|c|c|c|c|c|c|c|}
\hline Kelompok & $n$ & $\begin{array}{l}\text { Aklimatisasi } \\
\text { Rerata } \pm \text { SD } \\
\text { (g) }\end{array}$ & $\begin{array}{l}\text { Pengkondisian } \\
\text { Rerata } \pm \text { SD } \\
(\mathrm{g})\end{array}$ & $\begin{array}{l}\text { Intervensi } \\
\text { Rerata } \pm \text { SD } \\
\text { (g) }\end{array}$ & p1 & p2 \\
\hline Kontrol & 5 & $183,56 \pm 34,41$ & $223,92 \pm 25,34$ & $251,64 \pm 15,23$ & $0,001^{2}$ & $0,01^{2}$ \\
\hline Perlakuan yoghurt (P1) & 5 & $163,06 \pm 36,24$ & $208,84 \pm 19,30$ & $260,86 \pm 61,45$ & $0,068^{2}$ & $0,07^{2}$ \\
\hline Perlakuan soyghurt (P2) & 5 & $165,44 \pm 31,91$ & $206,80 \pm 25,48$ & $230,65 \pm 20,02$ & $0,001^{2}$ & $0,01^{2}$ \\
\hline$p$ value & & $\underline{0,664^{1}}$ & $0,439^{1}$ & $0,369^{1}$ & & \\
\hline
\end{tabular}


Tabel 3

Konsumsi Rerata Pakan Tikus Setiap Kelompok

\begin{tabular}{lcccccc}
\hline Kelompok & $\mathrm{n}$ & $\begin{array}{c}\text { Aklimatisasi } \\
\text { Rerata } \pm \text { SD } \\
(\mathrm{g})\end{array}$ & $\begin{array}{c}\text { Pengkondisian } \\
\text { Rerata } \pm \text { SD } \\
(\mathrm{g})\end{array}$ & $\begin{array}{c}\text { Intervensi } \\
\text { Rerata } \pm \text { SD } \\
(\mathrm{g})\end{array}$ & $\mathrm{p} 1$ & $\mathrm{p} 2$ \\
\hline Kontrol & 5 & $16,62 \pm 2,50$ & $15,94 \pm 0,84^{\mathrm{a}}$ & $15,61 \pm 1,62^{\mathrm{a}}$ & $0,486^{2}$ & $0,730^{2}$ \\
Perlakuan yoghurt (P1) & 5 & $15,31 \pm 2,38$ & $11,59 \pm 0,86^{\mathrm{b}}$ & $12,10 \pm 0,70^{\mathrm{b}}$ & $0,035^{2}$ & $0,111^{2}$ \\
Perlakuan soyghurt (P2) & 5 & $15,39 \pm 2,30$ & $11,57 \pm 0,91^{\mathrm{b}}$ & $13,09 \pm 0,73^{\mathrm{b}}$ & $0,008^{2}$ & $0,009^{2}$ \\
p value & & $0,262^{1}$ & $0,000^{1}$ & $0,002^{1}$ & & \\
\hline
\end{tabular}

p1 $p$ value pengkondisian, $\quad$ p2 p value intervensi, ${ }^{1} u j i$ one way Anova, ${ }^{2}$ paired t-test

$\left.{ }^{* *}\right)$ Notasi yang berbeda menunjukkan perbedaan yang bermakna pada uji lanjut LSD

Tabel 4

Perubahan Kadar Trigliserida dan Kolesterol Total Sebelum dan Sesudah Intervensi

\begin{tabular}{|c|c|c|c|c|c|}
\hline Kelompok & $\begin{array}{c}\text { Sebelum } \\
\text { Rerata } \pm \text { SD }\end{array}$ & $\begin{array}{c}\text { Sesudah } \\
\text { Rerata } \pm \text { SD }\end{array}$ & Penurunan & $\begin{array}{c}\% \\
\text { Perubahan }\end{array}$ & $p$ value \\
\hline \multicolumn{6}{|c|}{ Kadar Trigliserida } \\
\hline Kontrol & $78,00 \pm 18,53$ & $68,40 \pm 20,58$ & $9,60 \pm 15,34$ & 12,37 & $0,234^{2}$ \\
\hline $\begin{array}{l}\text { Perlakuan yoghurt } \\
\text { (P1) }\end{array}$ & $115,20 \pm 49,44$ & $102,14 \pm 34,36$ & $13,06 \pm 80,76$ & 11,34 & $0,736^{2}$ \\
\hline $\begin{array}{l}\text { Perlakuan soyghurt } \\
\text { (P2) }\end{array}$ & $115,06 \pm 25,49$ & $85,72 \pm 21,94$ & $29,34 \pm 42,60$ & 25,50 & $0,198^{2}$ \\
\hline$P$ value & $0,182^{1}$ & $0,172^{1}$ & $0,826^{1}$ & & \\
\hline \multicolumn{6}{|c|}{ Kadar Kolesterol Total } \\
\hline Kontrol & $71,64 \pm 13,07$ & $66,26 \pm 9,70$ & $5,63 \pm 16,2^{a}$ & 7,80 & $0,500^{2}$ \\
\hline Perlakuan yoghurt (P1) & $69,26 \pm 16,2$ & $65,34 \pm 13,4$ & $3,92 \pm 10,04^{a}$ & 5,65 & $0,672^{2}$ \\
\hline Perlakuan soyghurt (P2) & $65,42 \pm 5,4$ & $60,74 \pm 11,4$ & $4,68 \pm 11,72^{\mathrm{a}}$ & 7,10 & $0,431^{2}$ \\
\hline$P$ value & $0,733^{1}$ & $0,441^{1}$ & $0,644^{1}$ & & \\
\hline
\end{tabular}

\section{Konsumsi Rerata Pakan Tikus}

Konsumsi pakan kelompok kontrol tidak mengalami perubahan secara signifikan selama penelitian. Kelompok perlakuan 1 mengalami penurunan konsumsi pakan pada fase pengkondisian, sedangkan kelompok perlakuan 2 terjadi penurunan pada fase pengkondisian dan meningkat pada fase intervensi. Berdasarkan uji one way ANOVA, pada fase aklimatisasi, pakan tikus antar kelompok tidak berbeda secara signifikan. Pada fase pengkondisian dan intervensi terdapat perbedaan yang signifikan (Tabel 3).

\section{Kadar Trigliserida}

Berdasarkan Tabel 4, terjadi penurunan trigliserida pada semua kelompok setelah pemberian intervensi. Pada kelompok lainnya mengalami penurunan tetapi tidak secara signifikan. Penurunan kadar trigliserida terbesar terjadi pada kelompok P2 yaitu 25,50 persen. Berdasarkan uji one way ANOVA, kadar trigliserida sebelum dan sesudah perlakuan tidak berbeda secara signifikan antar kelompok

\section{Kadar Kolesterol Total}

Tidak terjadi penurunan kadar total kolesterol pada semua kelompok perlakuan secara signifikan. Penurunan kadar kolesterol total terbesar terjadi pada kelompok kontrol dengan penurunan sebesar 7,80 persen (Tabel 4). 


\section{BAHASAN}

Pada penelitian ini tikus dikondisikan mengalami pra sindrom metabolik dengan memberikan pakan tinggi lemak dan fruktosa selama 4 minggu. Kelompok tikus yang mengalami pra sindrom metabolik yaitu $\mathrm{P} 1$, dan P2 dengan terpenuhinya dua dari tiga faktor risiko yaitu hipertrigliserida, hiperglikemia dan $\mathrm{HDL}$ yang rendah. Pakan tinggi lemak yang diberikan yaitu asupan lemak jenuh berasal dari kuning telur puyuh dan minyak babi. Pemberian pakan tinggi lemak dan fruktosa ini akan menyebabkan peningkatan kadar trigliserida melalui peningkatan lipogenesis dan peningkatan produksi asam lemak bebas sehingga terjadi mobilisasi asam lemak bebas dari jaringan lemak menuju ke hepar dan berikatan dengan gliserol sehingga membentuk trigliserida. ${ }^{19}$

Berdasarkan uji paired t-test, terdapat peningkatan berat badan yang signifikan pada fase aklimatisasi, pengkondisian pra sindrom dan intervensi, kecuali kelompok perlakuan 1 pada fase intervensi $(p>0.05)$. Berdasarkan uji one way ANOVA, tidak terdapat perbedaan signifikan antar kelompok pada semua fase baik aklimatisasi pengkondisian pra sindrom metabolik dan intervensi. Peningkatan ini dipengaruhi oleh konsumsi pakan sebelum intervensi dan variasi perlakuan. ${ }^{20}$ Besarnya asupan makan berpengaruh terhadap besarnya asupan energi yang kemudian disimpan sebagai lemak dan akhirnya berimplikasi terhadap penambahan berat badan hewan coba. ${ }^{21}$

Asupan pakan standar selama pemberian pakan tinggi lemak menurun dan meningkat kembali setelah pemberian intervensi. Pada masa pengkondisian kelompok P1 dan P2 memiliki konsumsi pakan yang lebih sedikit daripada kelompok kontrol. Penurunan asupan pakan pada kelompok dengan tikus pra sindrom metabolik disebabkan karena pakan tinggi lemak dan fruktosa dapat memperlambat waktu pengosongan lambung sehingga tikus mengonsumsi pakan standar lebih sedikit jika dibandingkan pada tahap aklimatisasi. ${ }^{19}$

Sementara terdapat peningkatan asupan pakan yang signifikan pada masa intervensi berhubungan dengan adanya kondisi resistensi insulin. Hal ini akan menyebabkan kinerja leptin untuk memberikan sinyal kenyang ke otak terganggu, sehingga tubuh terus merasakan lapar. Hasil ini sesuai dengan penelitian yang menjelaskan bahwa asupan pakan standar pada saat pemberian diet tinggi lemak lebih rendah dibandingkan dengan pemberian pakan standar saja. ${ }^{19}$ Rerata asupan pakan kelompok $\mathrm{P} 1$ dan $\mathrm{P} 2$ lebih rendah dari pada kelompok $\mathrm{K}$, hal ini disebabkan oleh kandungan serat dalam yoghurt maupun soyghurt sinbiotik kayu manis.

Pada kelompok $\mathrm{K}$ mengalami penurunan kadar trigliserida dan total kolesterol meskipun tidak diberikan pakan intervensi. Penurunan ini diduga terjadi karena adanya serat dalam pakan standar. Penurunan kadar kolesterol dan trigliserida oleh serat dilakukan dengan cara mengikat asam lemak bebas serta kolesterol dalam bentuk asam empedu ketika dalam saluran pencernaan, kemudian dikeluarkan melalui feses. ${ }^{22}$

Selain karena komposisi pakan, penurunan kadar kolesterol total darah tikus $\mathrm{K}$ dengan sendirinya tanpa diberi perlakuan kemungkinan besar karena kenaikan kolesterol yang dialami tikus $\mathrm{K}$ masih dalam batas toleransi dimana tikus dapat melakukan mekanisme recovery untuk dapat menurunkan kadar kolesterol dengan sendirinya. ${ }^{22}$ Dilihat dari umur tikus yang digunakan, tikus berada pada usia dewasa sehingga jalur metabolismenya sudahbaik.

Terjadi penurunan trigliserida dan total kolesterol pada kelompok P1 dan P2, namun tidak signifikan. Hal ini dapat disebabkan oleh beberapa faktor seperti faktor genetik, umur dan jenis kelamin. ${ }^{23}$ Terdapat penelitian yang menunjukkan bahwa pemberian yoghurt tidak terdapat efek menurunkan trigliserida dan total kolesterol, hal tersebut diduga karena efek biologis yang dihasilkan berbeda pada setiap strain bakteri asam laktat, seperti resistensi asam, toleransi empedu, serta respon sel setiap individu. ${ }^{24}$

Diketahui bahwa rata-rata kadar kolesterol total hewan coba setelah diberi diet tinggi lemak berkisar 65,42 - 71,64 mg/dl. Sementara diketahui bahwa rata-rata kadar kolesterol total normal tikus Sprague Dawley berkisar 47 - 88 $\mathrm{mg} / \mathrm{dl}$. Pemberian diet tinggi lemak pada penelitian ini dapat dikatakan tidak sampai membuat hewan coba tersebut dalam keadaan hiperkolesterolemia. Kadar kolesterol total hewan coba saat diberi perlakuan masih dalam nilai normal sehingga penurunan kadar total kolesterol setiap kelompok perlakuan tidak 
representatif terhadap efek pemberian diet yang diberikan. Hal ini digambarkan dengan tidak adanya perbedaan yang signifikan antar kelompok perlakuan. Hal tersebut merupakan manifestasi dari homeostasis tubuh yaitu apabila kadar kolesterol total dalam tubuh masih tergolong normal maka tingkat penurunannya cenderung tidak signifikan. ${ }^{25}$

Penurunan kadar trigliserida dan kolesterol total pada kelompok P2 lebih besar dari kelompok P1 dengan penurunan sebesar 25,50 persen. Hal ini dikarenakan kacang kedelai pada soyghurt mengandung isoflavon dan lesitin. Isoflavon pada kacang kedelai terdiri atas genistin, daidzin dan glicitin. Mekanisme penurunan kolesterol oleh isoflavon dijelaskan melalui pengaruh isoflavon terhadap peningkatan katabolisme sel lemak untuk pembentukan energi, yang berakibat pada penurunan kandungan kolesterol. ${ }^{26}$ Selain itu, kacang kedelai pada penelitian ini telah melalui proses pengolahan yaitu fermentasi dengan menggunakan bakteri asam laktat.

Produk olahan kacang kedelai lebih berpotensi menurunkan kadar kolesterol serum dibandingkan kacang kedelai tanpa olahan. Hal tersebut dikarenakan pada pengolahan kacang kedelai terjadi proses hidrolisis senyawa isoflavon menjadi senyawa isoflavon bebas (aglikon) yang lebih tinggi aktivitasnya dalam menurunkan kadar kolesterol serum. Senyawa aglikon tersebut adalah genistein, glisitein, dan daidzein. ${ }^{13}$ Penelitian menunjukkan pengolahan fermentasi akan menghasilkan senyawa isoflavon bebas yang tertinggi. Fermentasi susu menggunakan bakteri asam laktat dapat menurunkan kadar kolesterol secara langsung melalui mekanisme asimilasi kolesterol dan secara tidak langsung melalui mekanisme dekonjugasi garam empedu. 5,6,7

Penyebab lainnya penurunan kelompok P2 lebih tinggi dibandingkan P1 yaitu protein kacang kedelai pada soyghurt dapat meningkatkan enzim lipoprotein lipase atau LPL, merupakan enzim yang berfungsi menghidrolisis trigliserida menjadi asam lemak bebas dan gliserol. Hal ini menyebabkan kadar trigliserida dalam tubuh pun menurun. ${ }^{27}$ Salah satu jenis protein yang banyak terkandung dalam kedelai yaitu arginin. Arginin merupakan substrat yang siap disintesis untuk menghasilkan Nitric Oxide (NO) dengan bantuan enzim NO Synthases (NOSs).
Mekanisme arginin terhadap profil lipid yaitu melalui melalui mekanisme penurunan lipogenesis oleh NO. NO dapat bersifat seperti antioksidan, ia dapat bereaksi cepat dengan anion superoksida (O-) yang kemudian dipromosikan untuk terbentuk radikal hidroksil $(\mathrm{OH}) .28$

Protein pada kacang kedelai dapat menurunkan kadar trigliserida, hasil ini sesuai dengan hasil penelitian yang menyatakan protein kacang kedelai dapat menurunkan trigliserida sebesar 12,4 persen, kolesterol total sebesar 4,4 persen, dan kolesterol LDL sebesar 5,7 persen jika dibandingkan protein hewani. Terjadi penurunan laju sintesis fraksi asam lemak trigliserida sebesar 13,3 persen. ${ }^{29}$

Selain isoflavon dan protein yang dapat menurunkan kolesterol dan trigliserida, kacang kedelai juga mengandung lesitin. Lesitin dapat mengurangi kadar trigliserida dengan berikatan pada Peroxisome Proliferator-Activated Receptor Alpha (PPAR-a) yang berperan dalam metabolisme lemak. Phosphatidylcoline dalam lesitin mengaktivasi PPAR-a. Aktivasi PPAR-a akan menurunkan kadar trigliserida melalui induksi oleh gen yang bertugas menurunkan ketersediaan trigliserida dalam Very Low Density Lipoprotein (VLDL) yang dihasilkan oleh hati. ${ }^{30}$

Serat yang terkandung dalam kacang kedelai dapat membantu menurunkan trigliserida. Serat pada kacang kedelai mempengaruhi metabolisme trigliserida dalam tubuh. Serat larut air berfungsi dalam memperlambat waktu pengosongan lambung, meningkatkan ketebalan lapisan intestinal yang berfungsi sebagai tempat absorpsi lipid. Selain itu, serat larut air dapat menghambat absorpsi dan metabolisme asam empedu dengan cara mengikat asam empedu dan meningkatkan pengeluarannya melalui feses. ${ }^{29}$

Pada penelitian ini, yoghurt kayu manis memberikan efek penurunan yang lebih rendah dibandingkan dengan soyghurt kayu manis. Hal ini dikarenakan komposisi lemak pada susu sapi lebih banyak dari pada susu kedelai. Dalam 249 $\mathrm{g}$ susu sapi mengandung $8,15 \mathrm{~g}$ lemak sedangkan susu kedelai hanya mengandung 4,67 g lemak saja dan tidak mengandung kolesterol. ${ }^{31}$ Penurunan yang terjadi pada pemberian yoghurt dikarenakan adanya bakteri probiotik yang dapat mengikat trigliserida dan kolesterol dalam darah sehingga tidak 
diabsorbsi oleh usus dan mengakibatkan kadar trigliserida dan kolesterol tubuh menurun. ${ }^{10}$

Penambahan kayu manis

(Cinnamomum burmanii) pada yoghurt dan soyghurt juga sebagai salah satu sumber antioksidan. Tanaman herbal kayu manis mengandung cynamaldehide yang merupakan turunan dari senyawa polifenol dan bersifat sebagai antioksidan. Polifenol menurunkan absorbsi kolesterol dengan cara berikatan pada cholesterol carriers saat melewati membran brush border. Kandungan cinnamate pada kayu manis juga dapat menghambat aktivitas HMGCoA reduktase hepar dan menurunkan peroksidasi lipid di hepar. Pada penelitian sebelumnya, pemberian minuman serbuk instan kayu manis dapat menurunkan kadar kolesterol total tikus namun tidak secara signifikan. ${ }^{32}$

Keterbatasan penelitian ini adalah menggunakan subjek pra sindrom metabolik yang memenuhi 2 dari 3 kriteria sindrom metabolik yang berbeda. Selain itu tidak semua subjek mengalami hiperkolesterolemia, yang berpengaruh pada perubahan rata-rata nilai kolesterol totalnya.

\section{SIMPULAN DAN SARAN}

\section{Simpulan}

Tidak terdapat pengaruh pemberian yoghurt maupun soyghurt sinbiotik kayu manis terhadap penurunan serum trigliserida dan kolesterol total.

\section{Saran}

Perlu dilakukan penelitian lanjutan pada kondisi pra sindrom metabolik dengan dua kriteria sindrom metabolik yang sama, dengan dosis yang lebih tinggi atau durasi yang lebih lama.

\section{UCAPAN TERIMA KASIH}

Terima kasih kepada LPPM Universitas Diponegoro yang telah mendanai penelitian ini dengan sumber dana selain APBN DPA SUKPA LPPM Universitas Diponegoro melalui skim Riset Penelitian dan Pengembangan (RPP).

\section{RUJUKAN}

1. Miranda PJ, DeFronzo RA, Califf RM, Guyton JR. Metabolic syndrome:
Definition, pathophysiology, and mechanisms. Am Heart J. 2005;149(1):33-45.

2. Kim SH, Kim K, Kwak MH, Kim HJ, Kim $\mathrm{HS}$, Han KH. The contribution of abdominal obesity and dyslipidemia to metabolic syndrome in psychiatric patients. Korean J Intern Med. 2010;25(2):168-73.

3. Sudoyo AW, Bambang S, Idrus A, Simadibrata M, S S. Buku Ajar IImu Penyakit Dalam Jilid III. Edisi IV. Internal Publishing; 2010. 26-28 p.

4. Cahjono $\mathrm{H}$, Budhiarta AAG. Hubungan Resistensi Insulin dengan Kadar Nitric Oxide Pada Obesitas Abdominal. J Intern Med. 2007:8:23-36.

5. Pratama SE, Probosari E. Pengaruh Pemberian Kefir Susu Sapi Terhadap Kadar Kolesterol LDL Tikus Jantan Sparague Dawley Hiperkolesterolemia. J Nutr Coll. 2012;1(1):358-64.

6. Dora I. A. Pereira and Glenn R. Gibson. Dual Effects of Lactobacilli as a Cholesterol Assimilator and an Inhibitor of Gastrointestinal Pathogenic Bacteria. Appl Environ Microbiol. 2006;2(3):1-5.

7. Pigeon R, EP C, Gililiand S. Bile salt deconjugation ability of free bile acids by cells of yoghurt starter culture bacteria. J Diary Sci. 2002;85(11):2705-10.

8. Flore $E$, Ngongang $T$, Tiencheu $B$, Achidi AU, Fossi BT, Shiynyuy DM, et al. Effects of Probiotic Bacteria from Yogurt on Enzyme and Serum Cholesterol Levels of Experimentally Induced Hyperlipidemic Wistar Albino Rats. 2016;4(6):48-55.

9. Baiduri I, Murwani H. Pengaruh pemberian yoghurt kedelai hitam. Artik Penelit Prodi Ilmu Gizi, FK Undip. 2011;

10. El-Zahar KM, Zaher AMA, Bassion HE. Effect of probiotic yoghurt on some metabolic parameters in hypercholesterolemic rats. Wulfenia J. 2014;21(April):57-79.

11. SI U, Ozdemir U, MS I. The Effect of Soybean Extracts on Serum Lipid Profile and the Accumulation of Free Cholesterol and Cholesteryl Ester in the Aorta, Carotid Artery and lliac ArteryExperimental Study. J Food Process 
Technol. 2016;7(9).

12. Pramesti AA, Artasurya MI. Pengaruh Pemberian Yoghurt Kacang Merah Terhadap Kadar Trigliserida Pada Wanita Disiplidemia. J Nutr Coll. 2015;4(2):288-94.

13. Riyanto S. Yoghurt Kedelai Hitam (Black soyghurt) Dapat Menurunkan Kadar LDL Tikus Hiperkolesterolemia. J Gizi dan Diet Indones. 2016;3(1):1-9.

14. Handayani DH, Sudistuti, Sudrajat. Pengaruh Infusa Herbal Kulit Kayu Manis ( Cinnamomum burmanii ) Dengan Buah Mahkota Dewa ( Phaleria macrocarpa ( Scheff .) Boerl .) Dan Daun Teh Afrika ( Vernonia amygdalina ) Terhadap Kadar Gula Darah Mencit ( Mus musculus L .) Diabetesi. In: Prosiding Seminar Sains dan Teknologi FMIPA Unmul, Periode Maret 2016, Samarinda, Indonesia. Samarinda, Indonesia; 2016. p. 1-4.

15. Hamid A, Azam AZ, Islam M, Al-Mamun R, Chowdhury J. Lipid Lowering Activity and Free Radical Scavenging Effect of Cinnamomum tamala (Fam: Lauraceae). Int J Nat Sci. 2012;1(4):936.

16. Hardoko. Pengaruh Konsumsi Kappa Karagenan Terhadap Glukosa Darah Tikus Wistar (Ratus norvegicus) Diabetes. J Teknol dan Ind Pangan. 2006;XVII:67-75.

17. Tejo VK, Karsodihardjo S, Ananingsih VK. Stevia Rebaudiana: an Excellent Natural Alternative for Sugar Replacer. In: The Third International Congress on Interdisciplinary Research and Development. Thailand; 2013. p. 3.13.4 .

18. Kaminskas A, Abaravičius JA, Liutkevičius A, Jablonskiene $V$, Valiuniene $J$, Bagdonaite $L$, et al. Quality of yoghurt enriched by inulin and its influence on human metabolic syndrome. Vet ir Zootech. 2013;64(86):23-8.

19. Tsalissavrina I, Wahono D, Handayani D. Pengaruh Pemberian Diet Tinggi Karbohidrat Dibandingankan Diet Tinggi Lemak Terhadap Kadar Trigliserida dan HDL Rendah Pada Rtus norvegicus galur wistar. Junal Kedokt Brawijaya.
2006;22(2):80-9.

20. Soesanto E, Ariyadi T. Pengaruh Pemberian Ekstrak Rebung Bambu Apus Terhadap Proporsi Kenaikan Berat Badan Tikus Putih (Rattus norvegicus strain wistar) Jantan. In: Prosiding Seminar Nasional\& Internasional. Semarang: Lembaga Penelitian dan Pengabdian Kepada Masyarakat Universitas Muhammadiyah Semarang; 2014. p. 1-6.

21. Millan Nuñez-Cortés $J$, Pedro-Botet $J$, Brea-Hernando Á, Díaz-Rodríguez Á, González-Santos P, Hernández-Mijares $A$, et al. Consenso de expertos sobre propuestas para la mejora del manejo de la dislipemia aterogénica. Rev Esp Cardiol. 2014;67(1):36-44.

22. Sigit $\mathrm{S}$, Enggar $\mathrm{P}$, Endah $\mathrm{H}$, Utama $\mathrm{S}$. Potensi Sari Kedelai Hitam dan Sari Kedelai Kuning Terhadap Kadar TrigliseridaTikus ( Rattus norvegicus ) dengan Diet Tinggi Lemak. 2010;3(1):57-60.

23. Ooi LG, Liong MT. Cholesterol-lowering effects of probiotics and prebiotics: A review of in Vivo and in Vitro Findings. Int J Mol Sci. 2010;11(6):2499-522.

24. Cheng Chih T, Lan Chun C, Shu E L, Chung Chih $\mathrm{H}$. Effect of cholesterol lowering multiplex lactic acid bacteria on lipid metabolism in a hamster model. African J Microbiol Res. 2016;10(20):708-16.

25. Gross DR. Animal Model in Cardiovascular Research. New York: Springer Science And Bussiness Media; 2009.

26. Atun S. Potensi Senyawa Isoflavon Dan Derivatnya Dari Kedelai (Glycine Max. L) Serta Manfaatnya Untuk Kesehatan. In: Prosiding Seminar Nasional Penelitian, Pendidikan, dan Penerapan MIPA, Fakultas MIPA, Uiversitas Negeri Yogyakarta. Yogyakarta; 2009. p. 3341.

27. G EE, E CO, K EA, S IO, O A, O MO. Effect of soy protein on serum lipid profile and some lipid-metabolizing enzymes in cholesterol fed rats. African J Biotechnol. 2016;6(19):2267-73.

28. Rezaei A, Li D, Han M, Wu G, Hu S, Ma $X$. L-Arginine Modulates Glucose and 
Lipid Metabolism in Obesity and Diabetes. Curr Protein Pept Sci. 2017;18(6):599-608.

29. Nurcahyanintyas $\mathrm{H}$. Efek

Antihiperlipidemia Susu Kacang Kedelai (Glycine Max (L.) Merr.) Pada Tikus Putih Jantan yang Diberi Diit Tinggi Kolesterol dan Lemak. Universitas Indonesia; 2012.

30. Moriel P, Mourad AM, De Carvalho Pincinato E, Mazzola PG, Sabha M. Influence of soy lecithin administration on hypercholesterolemia. Cholesterol. 2010;2010(June 2014).
31. Hajirostamloo $B$, Mahastie $P$. Comparison of Nuttritional and Chemical Parameters of Soymilk and Cow Milk. Res J Biol Sci 3. 2008;3(11):1324-6.

32. Vanessa $R$, Maria $L$, Purwijantiningsih E, Aida $Y$. Pemanfaatan minuman serbuk instan kayu manis (Cinnamon burmanii BI.) Untuk Menurunkan Kadar Kolesterol Total Darah Pada Tikus Putih (Ratus norvegicus). Universitas Atma Jaya Yogyakarta; 2010. 